Framework for Modeling Statewide Freight Movement Using Publicly Available Data Author(s): Subhro Mitra and Denver Tolliver

Source: Journal of the Transportation Research Forum, Vol. 48, No. 2 (Summer 2009), pp. 83-102

Published by: Transportation Research Forum

Stable URL: http://www.trforum.org/journal

The Transportation Research Forum, founded in 1958, is an independent, nonprofit organization of transportation professionals who conduct, use, and benefit from research. Its purpose is to provide an impartial meeting ground for carriers, shippers, government officials, consultants, university researchers, suppliers, and others seeking exchange of information and ideas related to both passenger and freight transportation. More information on the Transportation Research Forum can be found on the Web at www.trforum.org. 


\title{
Framework for Modeling Statewide Freight Movement Using Publicly Available Data
}

\author{
by Subhro Mitra and Denver Tolliver
}

This paper presents a methodology to model statewide truck trips using publicly available data developed by federal and state organizations. This methodology is applied for the statewide freight planning of North Dakota. In the absence of ample research funding, states, counties and metropolitan planning organizations can resort to these freely available data. A state level commodity-by-industry input-output table customized from a freely available national input-output table is used to disaggregate trips to the traffic analysis zone level. These databases are available nationally; hence, the methodology discussed in this paper can be transferred to other states with relative ease.

\section{INTRODUCTION}

Transportation planners are intimidated by the lack of data whenever they embark on a project involving freight movement - whether on a national, statewide or regional scale. Statewide freight planning is undertaken by Departments of Transportation (DOTs) and research organizations at different levels of accuracy and levels of disaggregation based on the research objectives and funds allocated for the project. There is literature on data requirements and data available for freight planning. A National Cooperative Highway Research Program (NCHRP) report on requirements of freight data for transportation planning (Roger Creighton Associates and R.L. Banks \& Associates 1977) presents a catalog of freight data sources for use by state and regional planners. This manual is outdated, as there are many additions and alterations in the data sources. Similarly, the Directory of Transportation Data Sources (Bureau of Transportation Statistics 1995) is also now obsolete, as there are many additions and alterations to its list of data sources.

The Federal Highway Administration (FHWA) has acknowledged the importance of freight modeling and has a website dedicated to improving freight models (U.S. Department of Transportation 2007b). This "Freight Model Improvement Program" is a joint effort by the U.S. Department of Agriculture, the U.S. Department of Energy and the U.S. Army Corps of Engineers and is supported by the Oak Ridge National Laboratory. This website provides information about major sources of national freight transportation data. Top on the list is the Commodity Flow Survey (CFS) (U.S. Census Bureau 2007b). Freight Analysis Framework (FAF) (U.S. Department of Transportation 2007a), GeoFreight (U.S. Department of Transportation 2007c), Rail Waybill Data (Surface Transportation Board 2007), Maritime Statistics (U.S. Department of Transportation 2007d), and Waterborne Commerce of the United States (U.S. Army Corps of Engineers 2007) are other sources referred to in this website.

The Transportation Research Board (TRB) conducted a study to gain insight into various freight data needed by different users for freight planning, as well as to identify different freight data providers (Donnelly 2003). This study identifies different attributes of freight movement that are part of freight data, namely origin and destination, commodity characteristics, modes of movement, routing and vehicle configuration. This report, published by TRB, identifies the CFS and the Transearch database from Global Insight (2006) as the most comprehensive freight flow data in the country. This report also points out that these databases have their own deficiencies. FAF overcomes some of the deficiencies of the CFS data by incorporating CFS "out of scope data," 
comprised of goods generated from imports, publishing, farms, construction, logging services and fisheries.

This paper outlines a methodology to model statewide freight flow using publicly available data, which are freely downloadable from websites hosted by federal and state entities. This methodology, along with these databases, can be successfully used to estimate a truck origin-destination (OD) matrix disaggregated to transportation analysis zone (TAZ) levels, which are counties in this project.

Most freight models lack logistics aspects (De Jong and Ben-Akiva 2007). In the absence of detailed survey data of warehouse locations and distribution centers, truck count data from the state DOT and the matrix estimation method are used to introduce distribution legs in the OD pairs. This methodology, even with its shortcomings, produces a fairly good statewide freight model and is used to assess economic impacts of infrastructure investment in the state and various other facility location studies associated with freight movement.

In this statewide freight planning project, agricultural goods and commodities other than agriculture, ${ }^{1}$ consisting of manufactured goods and mining products, are modeled separately. The data for the manufactured goods are obtained from the second generation freight analysis framework $\left(\mathrm{FAF}^{2}\right)$ data, developed by the FHWA. The OD data, obtained from $\mathrm{FAF}^{2}$, has origins and destinations as states and sub-state regions. ${ }^{2}$ This OD data are disaggregated to the TAZ level using population and employment information available from County Business Patterns (CBP) data, which is developed by the U.S. Census Bureau (2007a), and commodity by industry inputoutput (I-O) tables, which are developed by Bureau of Economic Analysis (2006). The national $\mathrm{I}-\mathrm{O}$ table is scaled down to the state level using the location quotient and is explained in detail later in this paper. In some statewide freight models, as in the Montana highway reconfiguration study, disaggregation of OD data is done using Implan Professional software (Minnesota Implan Group 2007). In the modeling framework discussed in this paper, no such professional software is used for disaggregation.

Some of the tasks undertaken in this project include:

- Identify sources of manufactured freight movement data, as well as data required for disaggregating flows in the public domain.

- Combine data from heterogeneous sources, such as public domain data and local survey results.

- Develop a methodology to subdivide the statewide freight model into commodity-based sub-models for analytical purposes and finally merge them into one.

The CFS does not provide any information about crop movement from fields to elevators. States like North Dakota, where agricultural production dominate the state economy, trucks hauling crops from fields to elevators account for a big share of freight movement in the state. In this project, data for agricultural freight are developed from satellite imagery of crop data layers (Mitra et al. 2007). This paper does not discuss the methodology for modeling agricultural freight; it only outlines the method for modeling manufactured goods.

\section{DATA SOURCES}

In this project, the main source of data is the second generation Freight Analysis Framework data $\left(\mathrm{FAF}^{2}\right)$, developed by the FHWA in cooperation with the Bureau of Transportation Statistics through Oak Ridge National Laboratory and MacrosSys Research and Technology (U.S. Department of Transportation 2007a). The commodity flow data available from FAF $^{2}$ are comprised of four dimensions: origin, destination, commodity and mode of transportation. The $\mathrm{FAF}^{2}$ data, like the CFS data, have 114 regions, 17 international gateways and seven international regions. These data have 43 two-digit standard classifications of transported goods (SCTG) classes of goods and seven modes of transport. This OD database has three categories of data, namely the CFS within scope data, auxiliary data and CFS "out-of-scope" data. 
Data available from different sources, such as the Carload Waybill sample (Surface Transportation Board 2007), Domestic Waterborne Commerce of the United States (U.S. Army Corps of Engineers 2007), International Waterborne Commerce of the United States (U.S. Army Corps of Engineers 2007), Transborder Surface Freight (Bureau of Transportation Statistics 2007), and U.S. Air Freight Movement (Bureau of Transportation Statistics 2007), are used in a log-linear model to fill in the voids of the CFS data. Certain classes of commodities are totally absent in the CFS database; some are partially absent, whereas some are in part of the supply chain. Class of commodities that are missing in the CFS data, but included in the FAF database, are farm-based products, fisheries, crude petroleum, natural gas, municipal solid waste, logging, construction, publishing, retail, imports, petroleum products, exports and in-transits. Three approaches are used to validate these data. In the first approach, a cell of the OD matrix is removed, the commodity OD data are estimated, and then the two tables are compared. In the second approach, a comparison is made between the derived parameters and the auxiliary data consisting of waterborne commerce, rail waybill and air carrier data. In the third validation approach, the absolute values of cell values calculated from out-of-scope commodities are compared to cell values calculated from auxiliary data sources (U.S. Department of Transportation 2007a).

The I-O commodity-by-industry coefficients are available from the benchmark I-O accounts developed by the U.S. Department of Commerce/Bureau of Economic Analysis (Bureau of Economic Analysis 2006). The 1997 benchmark I-O account, though out of date, is the most detailed commodity-by-industry account of the United States economy. In this study, the interactive table is used, where the user can aggregate commodities and industries according to his or her requirements. In the 1997 benchmark I-O account, there are commodity flows from 483 commodities groups to 491 industries and 13 end users. A salient feature of the 1997 I-O account is the classification of the commodities and industries based on the North American Industry Classification System (NAICS) as an alternative to the Standard Industrial Classification (SIC) classifications used in the previous year accounts.

\section{MODEL DESCRIPTION}

\section{Overview of the Model}

The basic modeling framework is shown in Figure 1. The prime source of data is the $\mathrm{FAF}^{2}$ data. Manufactured goods consist of commodities other than agricultural products, namely mining, construction, wholesale and retail trade, petroleum and coal products. FAF ${ }^{2}$ is a repository of OD data of manufactured goods moving in all modes of transport. In this statewide freight flow model, as we are interested with truck traffic only, manufactured goods transported in trucks are extracted from the database. In addition to 52 internal TAZs, there are 15 external TAZs, which are connected with the state highways at possible exits at the boundary locations with dummy links as shown in Figure 2 .

This modeling framework has three stages: trip generation, trip distribution and trip assignment. There is no mode choice stage in the model, as the OD data queried out from the $\mathrm{FAF}^{2}$ database are for truck only. The statewide freight flow model is broken into internal-external, internalinternal and external-external sub-models. The concept of onion model is used here, assuming that congestion is not an issue in most highway networks of the state. The onion model assignment is done in layers for individual commodities or sub-models, and the assigned network is finally merged to get the estimated trucks in the network. In this project, truck flow, assigned networks from the manufactured goods model, is merged with that from the agricultural freight flow model to get the total truck traffic in the network. 
Figure 1: Methodological Framework of the Manufacturers' Freight Model

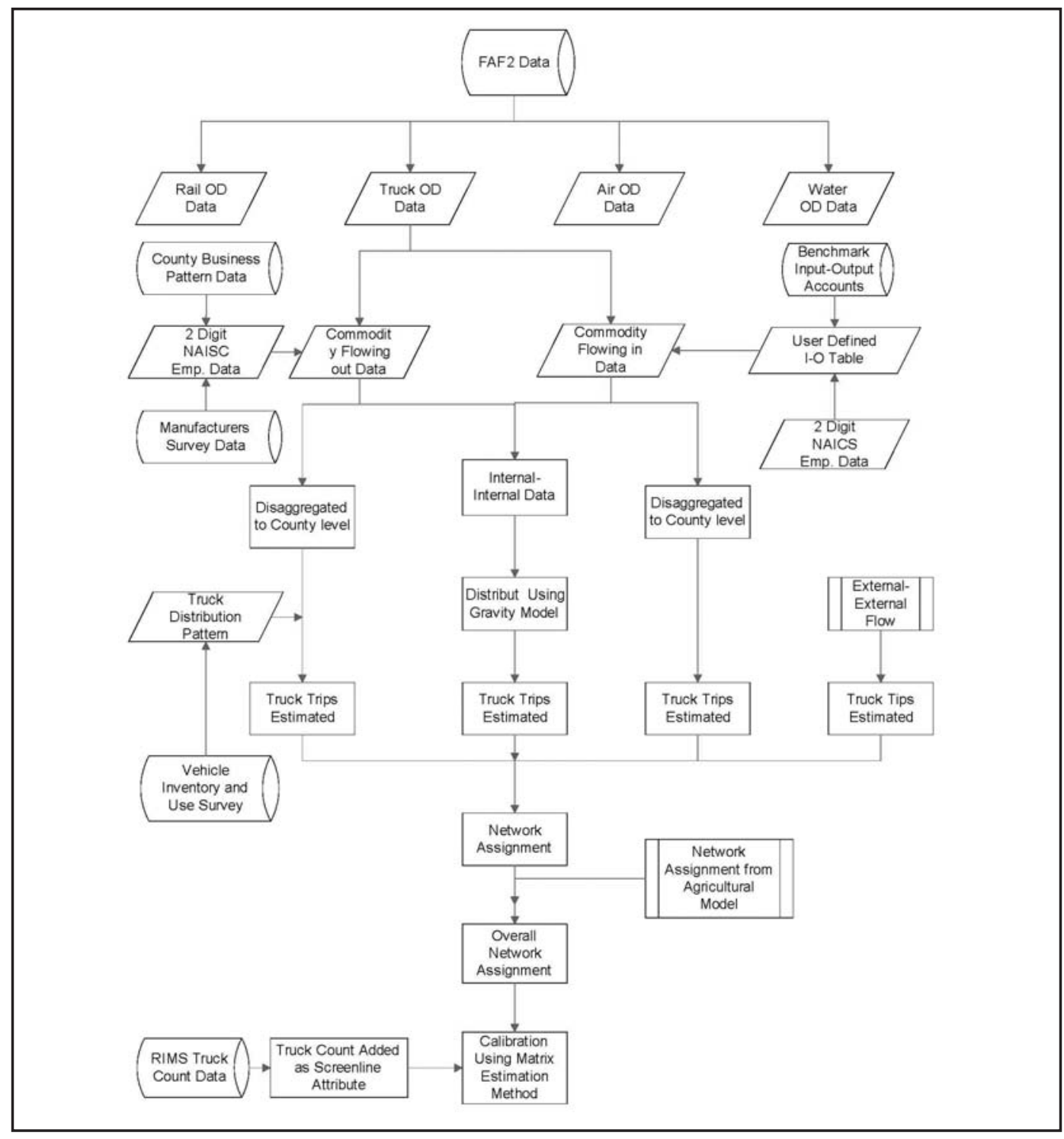

\section{Analyzing FAF Data}

The $\mathrm{FAF}^{2}$ is the source of freight movement OD data between states, sub-state regions and major international gateways. The $\mathrm{FAF}^{2}$ data, unlike the CFS data, provide both dollar value and tonnages for each OD pair; hence, it is not required to convert dollar value to tonnage using producer price indices (PPI). The first generation FAF data classified commodities based on Standard Transportation Commodity Code (STCC). In the second generation FAF, the goods are classified based on the Standard Classification of Transported Goods (SCTG), which is developed by the U.S. Department of Transportation, the U.S. Census Bureau and Statistics Canada. The SCTG covers goods in all modes of transport, and it results in uniformity of transportation data of the United States and Canada. SCTG also creates an integrated system of commodity classification for economic analysis and facilitates the North American Free Trade Agreement (NAFTA). 
Figure 2: Internal and External TAZ for the North Dakota Freight Flow Model

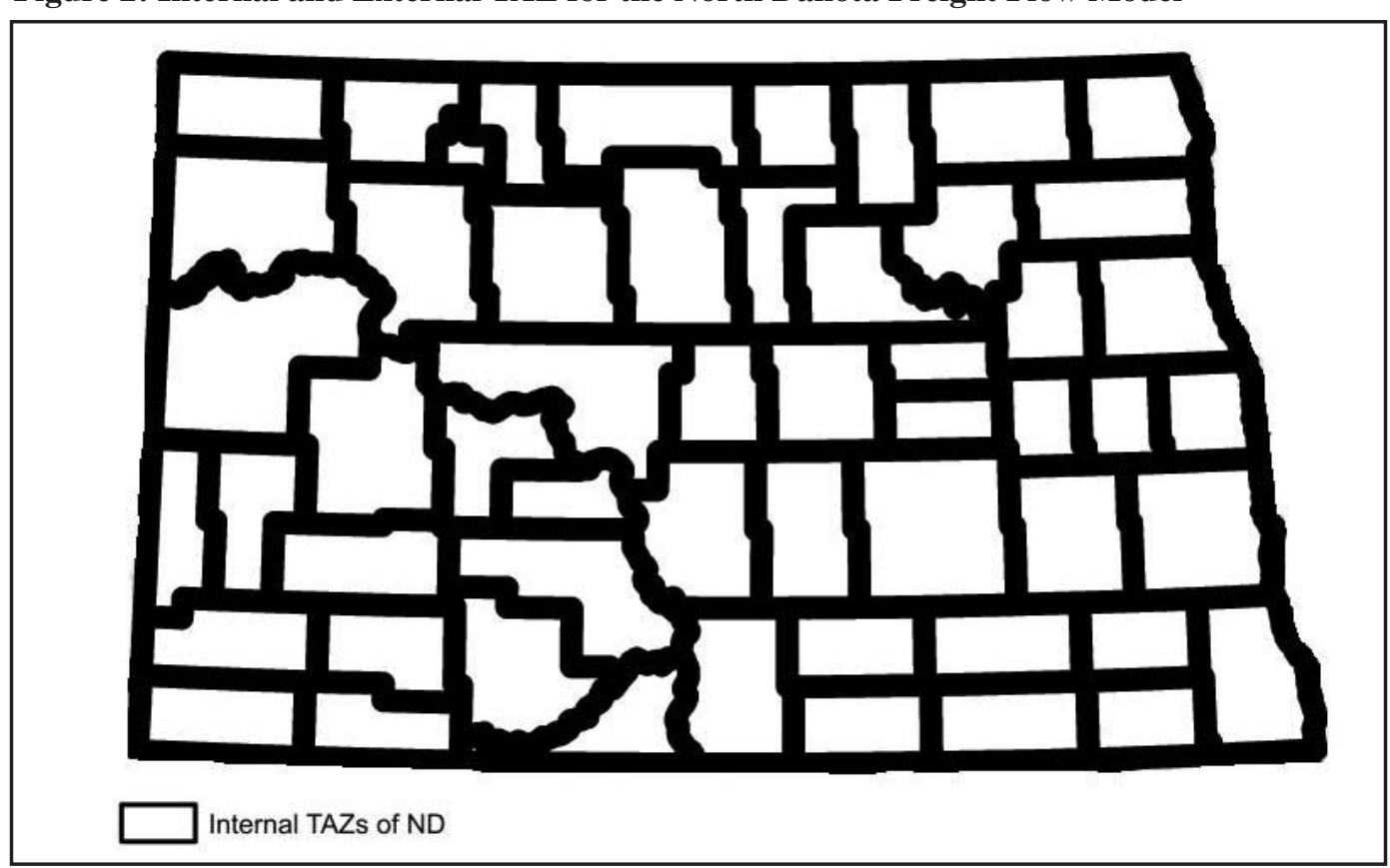

The $\mathrm{FAF}^{2} \mathrm{OD}$ data is a four-dimensional matrix - origin, destination, commodity and mode. The complete database is in Microsoft Access, and the name of the file is "FAFOD_2002.MDB." This file has information on commodity flows both within domestic regions and also to foreign countries. The Microsoft Assess table "FAFOD_DOM_2002" has the domestic origin and destination data; the "FAFOD_BRD_2002" table provides data for commodity movement across the border. The "FAFOD_SEA_2002" table has information about commodities transported by water. For this project, the two tables "FAFOD_2002.MDB" and "FAFOD_BRD_2002" are used, and required OD data are extracted using Structured Query Language (SQL). The first query is used to extract all OD data with origins in North Dakota and transported in trucks. From this list of commodities that moves out of North Dakota, 18 major commodities that make up approximately $97 \%$ of the total freight are selected, as shown in Table 1 . In this table, it is seen that cereal grain constitutes $54 \%$ of the total freight moving out. As agricultural freight is modeled separately, cereal grain is excluded from this list. Milled grain products are included in this list, because they were not included in the agricultural freight flow model. The two-digit level SCTG classifications and their descriptions are available from the Bureau of Transportation Statistics website. The two-digit level SCTG classes of the $\mathrm{FAF}^{2}$ commodities are added to the extracted OD data to facilitate further analysis. This SCTG classification helps in connecting a commodity to its producing industry, which is classified using North American Industrial Classification System (NAICS).

The freight moving out of the state has different domestic destinations. For the present model, 15 destinations are selected as shown in Figure 3. These destinations make up approximately 98\% of aggregated freight flowing out. It is seen that $77 \%$ of the commodities generated in North Dakota have a destination within North Dakota, as shown in Table 2. These commodities moving from and to North Dakota are modeled as internal-internal flow. The commodities moving across the state boundary to other states and Canada are modeled in the internal-external flow model. 
Statewide Freight Movement

Table 1: List of Major Commodities Moving Out of North Dakota

\begin{tabular}{l|c|c|c}
\hline Commodity & $\begin{array}{c}\text { Quantity in } \\
\text { Kilo-ton }\end{array}$ & $\begin{array}{c}\text { Percentage of } \\
\text { Total }\end{array}$ & SCTG Code \\
\hline Cereal grains & $47,011.9$ & $54.0 \%$ & 02 \\
Coal & $51,38.1$ & $5.9 \%$ & 15 \\
Waste/scrap & $4,881.0$ & $5.6 \%$ & 41 \\
Other ag prods. & $4,477.8$ & $5.1 \%$ & 03 \\
Gravel & $4,317.6$ & $5.0 \%$ & 12 \\
Gasoline & $3,847.6$ & $4.4 \%$ & 17 \\
Nonmetal min. prods. & $3,242.4$ & $3.7 \%$ & 31 \\
Fuel oils & $2,362.5$ & $2.7 \%$ & 18 \\
Coal, n.e.c. & $1,733.2$ & $2.0 \%$ & 19 \\
Other foodstuffs & $1,638.8$ & $1.9 \%$ & 07 \\
Unknown & $1,471.0$ & $1.7 \%$ & ---- \\
Animal feed & 843.3 & $1.0 \%$ & 04 \\
Machinery & 790.3 & $0.9 \%$ & 34 \\
Milled grain prods. & 578.9 & $0.7 \%$ & 06 \\
Natural sands & 562.0 & $0.6 \%$ & 11 \\
Mixed freight & 557.0 & $0.6 \%$ & 43 \\
Wood prods. & 547.5 & $0.6 \%$ & 26 \\
Live animals/fish & 417.6 & $0.5 \%$ & 01 \\
\hline
\end{tabular}

(U.S. Department of Transportation 2007a)

Figure 3: Commodities Moving to Major Destinations from North Dakota

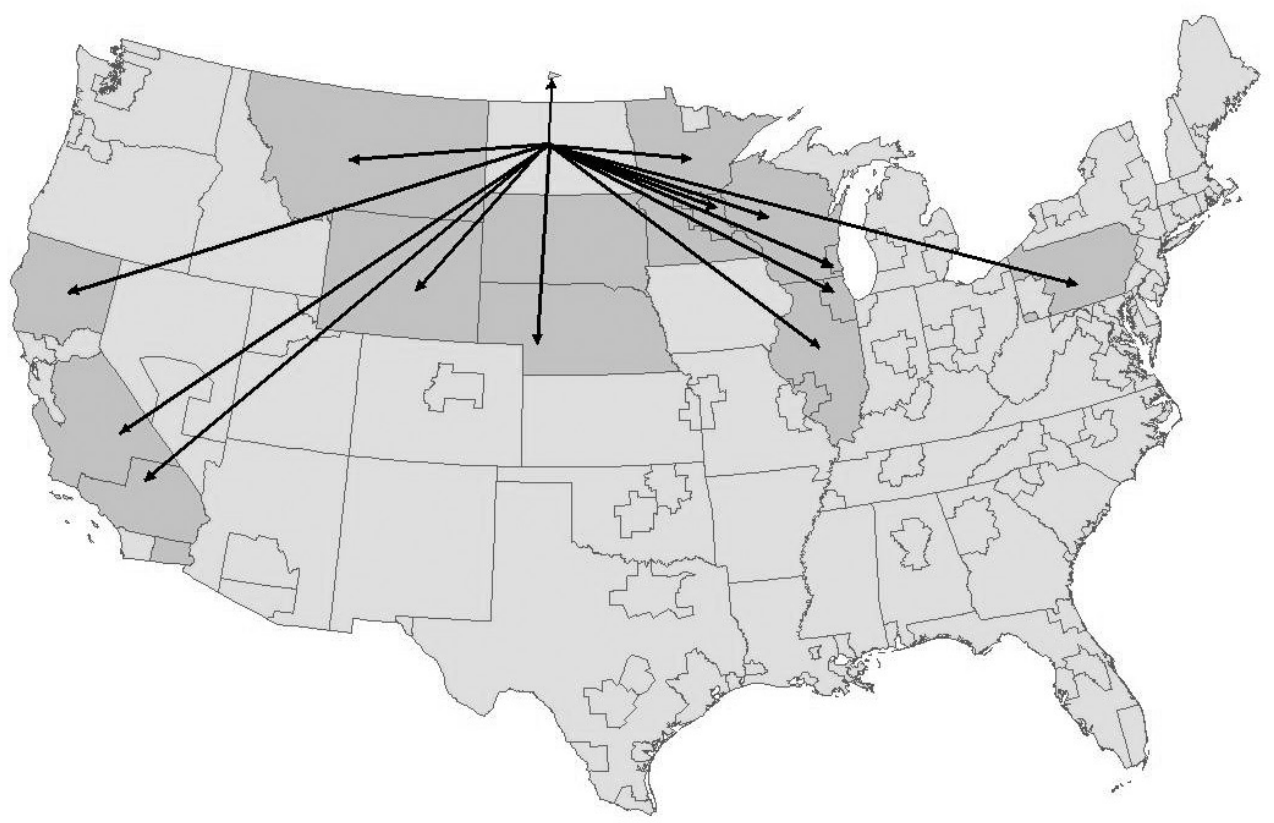


Table 2: Destination of Commodities Moving Out of North Dakota within United States

\begin{tabular}{llcc}
\hline Destinations & Description & $\begin{array}{c}\text { Quantity in } \\
\text { Kilo-tons }\end{array}$ & $\begin{array}{c}\text { Percentage of } \\
\text { Total }\end{array}$ \\
\hline ND & North Dakota & 67242.063 & $77.27 \%$ \\
MN remainder & Remainder of Minnesota & 11877.248 & $13.65 \%$ \\
MN Minneapolis & Minneapolis & 3097.741 & $3.56 \%$ \\
SD & South Dakota & 1416.059 & $1.63 \%$ \\
WI remainder & Wisconsin & 790.957 & $0.91 \%$ \\
MT & Montana & 439.593 & $0.51 \%$ \\
NE & Nebraska & 194.658 & $0.22 \%$ \\
IA & Iowa & 120.531 & $0.14 \%$ \\
IL Chicago & Illinois- Chicago & 115.738 & $0.13 \%$ \\
IL remainder & Illinois & 96.479 & $0.11 \%$ \\
CA remainder & Remaining of California & 85.62 & $0.10 \%$ \\
PA remainder & Remaining of Pennsylvania & 71.046 & $0.08 \%$ \\
IL St Louis & St. Louis Illinois & 65.136 & $0.07 \%$ \\
WI Milwaukee & Milwaukee Wisconsin & 57.322 & $0.07 \%$ \\
VT & Vermont & 55.306 & $0.06 \%$ \\
CA Los Angles & Los Angeles - Long Beach CA & 53.763 & $0.06 \%$ \\
WY & Wyoming & 48.596 & $0.06 \%$ \\
\hline US Departm & &
\end{tabular}

(U.S. Department of Transportation 2007a)

\section{Employment Distribution Pattern}

The statewide production data are further disaggregated to the county level using two-digit level NAICS county employment data available from the U.S. Census Bureau's County Business Patterns database (Vachal and Tolliver 2001) and supplemented by data available from the manufacturer's survey done at the Upper Great Plains Transportation Institute (UGPTI). CBP data are available from 1988 to 2005. Until 1997, the establishments were classified on the basis of standard industrial classification (SIC); henceforth the classification is based on the NAICS. Retail trade, wholesale trade and manufacturing are included in both of these systems, but they cover somewhat different groups of industries.

CBP has employment data for industries categorized to three-digit level NAICS. However, for most industries there is data suppression to avoid disclosure. Hence, it was decided to use twodigit level NAICS for classification of industries in the state. SCTG, which is a classification of commodities, and NAICS, which is a classification of industries, need to be linked. A bridge dataset provided by BTS serves the purpose of linking two-digit level SCTG to two- and three-digit level NAICS.

\section{Disaggregating Trip Generation}

The statewide production data are disaggregated to county level using two-digit NAICS county employment data. The basic assumptions for disaggregating state production data using county employment data are as follows:

- Manufacturing plant's output is proportional to the number of employees. 
- All plants in the same industry have the same productivity.

The ratio of county employment to employment in the entire state in a particular NAICS category determines the county production of that commodity.

(1) $t_{c j}^{a}=t_{j}^{a} \times e_{c}^{b} / \sum e^{b} \forall j$

$t_{c j}^{a}=$ tons of SCTG class $a$ commodity produced in county $c$ moving to destination $j$

$t_{j}^{a}=$ total tons of SCTG classification $a$ commodity produced in the state moving to destination $j$

$e_{c}^{b}=$ employment in industry $b$ in county $c$

$e^{b}=$ total employment in industry $b$ in the state

$a \quad=$ two-digit level SCTG commodity class

$b \quad=$ two-digit level NAICS industries class producing commodity $a$

An example of disaggregation methodology is illustrated in Table 3. The county employment distribution for NAICS category 21, which is the industry classification for mining products, is shown in row one of the table. Employment in this category is distributed within seven counties of the state of North Dakota. The second row of the table shows the estimated ratio of the county employment in NAICS 21 to the total employment in the NAICS 21 category in the state i.e. $e_{c}^{b} / \sum e^{b}$. The cell in the third row of the table shows the amount in Kilo-tons that moves from North Dakota to the eight major destinations. The ratios estimated in the second row are used to disaggregate the quantities in the third row to the county production, as shown in cells of row four to ten in Table 3. The amount of commodity 41.238 Kilo-tons as shown in row 4 moving from Burke county to ND is the product of 3686.06 Kilo-tons of commodity moving from ND to ND and the county employment ratio .01, as shown in row 2 . The difference of the result is because of rounding of the employment ratios in row 2.

\section{Trip Attraction}

From the FAF2's "FAFOD_DOM_2002" Microsoft Access table, data for all commodities moving into North Dakota by truck are extracted using an SQL query. From this list, 16 major FAF regions, as shown in Table 4, are selected that generate $99 \%$ of the freight moving into the state. Commodities originating and terminating in North Dakota make up the bulk of this OD data. This implies, as we have seen, that the biggest percentage of freight generated in the state has its destination within North Dakota. Those commodities, having their origins and destinations in North Dakota, are analyzed in the internal-internal module.

From this list of commodities moving in the state, 18 commodities are selected that make up 97\% of the total freight flow, as shown in Table 5. According to data in Table 5, 48\% of this freight is cereal grains. This is excluded from this manufactured goods model, as it is included in the agricultural freight flow model.

\section{Input-Output Analysis}

Disaggregation of trip attraction is not as simple as disaggregating trip production data. Trip attraction is based on the characteristics of the receiving industry and end users that consume the goods moving in the state. To link the goods moving in the state to the consuming industries and end users, a supply side commodity-by-industry I-O table is used. The FAF ${ }^{2}$ inbound traffic is disaggregated to the TAZ level based on the number of manufacturers and other economic sectors 
Table 3: Disaggregating Trip Production Data to County Level

\begin{tabular}{lrrrrrrrrr}
\hline & \multicolumn{6}{c}{ County Employment $\left(e_{c}^{b}\right)$} & \multicolumn{2}{c}{ Total Employment } & $\left(e_{c}^{b}\right)$ \\
\hline Row NAICS $(b)$ & Burke & Burleigh & McK enzie & Mercer & Stark & Ward & Williams & For all Counties \\
\hline 1 & 21 & 26 & 89 & 84 & 1249 & 274 & 273 & 329 & 2,324 \\
\hline 2 & $e_{c}^{b} / \sum e^{b}$ & 0.01 & 0.04 & 0.04 & 0.54 & 0.12 & 0.12 & 0.14 & \\
\hline
\end{tabular}

\begin{tabular}{|c|c|c|c|c|c|c|c|c|c|}
\hline & \multicolumn{7}{|c|}{ Commodity "a" shipped to destination "j" from North Dakota (Kilo-Tons) } & \multirow{2}{*}{$\frac{\left(t_{j}^{a}\right)}{W Y}$} \\
\hline & & IA & MN Minne & MN rem & MT & ND & SD & WI rem & \\
\hline \multirow[t]{3}{*}{3} & ND & 0.29 & 73.49 & 185.66 & 4.30 & 3686.06 & 364.32 & 2.58 & 0.93 \\
\hline & & \multicolumn{8}{|c|}{ Commodity "a" moving to destination "j" from county "c" (Kilo-Tons) $\left(t_{c j}^{a}\right)$} \\
\hline & & IA & MN Minne & MN rem & MT & ND & SD & WI rem & WY \\
\hline 4 & Burke & 0.003 & 0.822 & 2.077 & 0.048 & 41.238 & 4.076 & 0.029 & 0.010 \\
\hline 5 & Burleigh & 0.011 & 2.814 & 7.110 & 0.165 & 141.161 & 13.952 & 0.099 & 0.036 \\
\hline 6 & McK enzie & 0.011 & 2.656 & 6.711 & 0.155 & 133.231 & 13.168 & 0.093 & 0.034 \\
\hline 7 & M ercer & 0.156 & 39.494 & 99.779 & 2.311 & 1981.017 & 195.796 & 1.388 & 0.500 \\
\hline 8 & Stark & 0.034 & 8.664 & 21.889 & 0.507 & 434.587 & 42.953 & 0.305 & 0.110 \\
\hline 9 & Ward & 0.034 & 8.632 & 21.809 & 0.505 & 433.000 & 42.796 & 0.303 & 0.109 \\
\hline 10 & Williams & 0.041 & 10.403 & 26.283 & 0.609 & 521.821 & 51.575 & 0.366 & 0.132 \\
\hline
\end{tabular}

Table 4: FAF $^{2}$ Regions Generating Freight Moving in North Dakota

\begin{tabular}{lcc}
\hline Origin & $\begin{array}{c}\text { Quantity in } \\
\text { Kilo-tons }\end{array}$ & Percentage \\
\hline ND & 67,242 & $89.66 \%$ \\
MN remainder & 3,276 & $4.37 \%$ \\
MN Minneapolis & 1,212 & $1.62 \%$ \\
IL remainder & 640 & $0.85 \%$ \\
SD & 600 & $0.80 \%$ \\
MT & 390 & $0.52 \%$ \\
WI remainder & 269 & $0.36 \%$ \\
MO remainder & 250 & $0.33 \%$ \\
IA & 177 & $0.24 \%$ \\
IL Chicago & 118 & $0.16 \%$ \\
WY & 84 & $0.11 \%$ \\
ID & 54 & $0.07 \%$ \\
TN Memph & 47 & $0.06 \%$ \\
MI remainder & 43 & $0.06 \%$ \\
NE & 40 & $0.05 \%$ \\
CA remainder & 39 & $0.05 \%$ \\
\hline
\end{tabular}

(U.S. Department of Transportation 2007a) 
Table 5: Major Commodities Moving into North Dakota

\begin{tabular}{lcc}
\hline Commodity & Quantity in Kilo-tons & Percentage \\
\hline Cereal grains & 36,004 & $48.0 \%$ \\
Coal & 5,162 & $6.9 \%$ \\
Gravel & 5,009 & $6.7 \%$ \\
Waste/scrap & 4,872 & $6.5 \%$ \\
Other agri. prods. & 3,924 & $5.2 \%$ \\
Gasoline & 3,630 & $4.8 \%$ \\
Nonmetal min. prods. & 3,516 & $4.7 \%$ \\
Fuel oils & 2,090 & $2.8 \%$ \\
Coal, n.e.c. & 1,834 & $2.4 \%$ \\
Other foodstuffs & 1,308 & $1.7 \%$ \\
Unknown & 1,285 & $1.7 \%$ \\
Natural sands & 757 & $1.0 \%$ \\
Wood prods. & 720 & $1.0 \%$ \\
Mixed freight & 586 & $0.8 \%$ \\
Animal feed & 584 & $0.8 \%$ \\
Machinery & 582 & $0.8 \%$ \\
Nonmetallic minerals & 487 & $0.6 \%$ \\
Live animals/fish & 375 & $0.5 \%$ \\
\hline
\end{tabular}

(U.S. Department of Transportation 2007a)

in the TAZ. An I-O table gives a comprehensive snapshot of economic activities in a state or region for a period, say a year. It portrays the flow of goods from the producers to the manufacturers and end users. In the I-O table, the row sum gives the total sales of the sector, and the column sum gives the total input purchases of the sector. The basic principle of this table is that the sum of the input to an industry is equal to its output. The table can be divided into three components: inter-industry transaction, final demand and final payments. The inter-industry block includes transaction between the state's or region's industries. The final demand is the sales from industries to the end users, and final payments are the purchases of labor and capital by the industries of the region (Lawson et al. 1997).

The national I-O table is obtained from the BEA's Commodity-by-Industry 1997 benchmark I-O account. The 1997 benchmark account is more detailed than other annual accounts. This benchmark account shows the flow of 483 commodities to 491 industries and to 13 final users. The salient features of the 1997 I-O account are the introduction of the NAICS in place of SIC. This seems to be more relevant for service industries. This I-O account is more consistent with gross domestic product (GDP) by industry accounts and gross state products of industries. This benchmark I-O account has the advantage of being downloadable at different levels of aggregation. The I-O classification system is based on the NAICS classification, but it also considers special industries and government industries. The commodities in the I-O classification system are given the code of the industry that produces that commodity. The summary I-O table is aggregated to 38 commodity and industry user-defined categories (Liu and Vilain 2004). Lawson et al. (1997), in their explanation of the benchmark input-output accounts, provides the NAICS class corresponding to the I-O account's classification. For each of the 38 industries, the three-digit level NAICS class is identified. For the commodities, it is convenient to identify the I-O group in which they fall. In 
the I-O accounts table, there are some negative entries in column 38. These negative entries reflect import of the commodities from other countries. The value of imports in the producer's price is the negative value entered in the final demand column. The regional I-O table is developed from the Bureau of Economic Analysis's (BEA) benchmark I-O account and location coefficients for each level of commodity aggregation. The user-defined 38 categories and their corresponding NAICS are shown in Table 6.

\section{Disaggregating Trip Attraction}

The $\mathrm{FAF}^{2}$ inbound traffic is disaggregated to the TAZs of the state (Figure 2) based on the number of manufacturers and other economic sectors in the TAZ. The assumptions for using the I-O table as stated in NCHRP 260 are as follows (Memmott 1983):

- Freight shipments are proportional to the dollar outputs contained in the table.

- All plants in the same commodity group have production in proportion to the number of employees in the plant.

- All receivers in the same industry share the resulting commodity flow proportionally.

The first step of the disaggregation methodology is to download the user-defined I-O table. In this table, there are 38 rows and 38 columns. The rows represent the amounts of commodities in (million) dollar values used by the industries and final users.

(2) $U=\left[U_{i j}\right]$

$\mathrm{U}$ is an $m$ by $n$ matrix with each element representing the amount of commodity $i$ in dollar value used by industry $j$ as input

(3) $A=U .1$

$\mathrm{A}_{\mathrm{i}}=$ total amount of commodity $i$ used by industry and end user

$\mathbf{1}=\left[\begin{array}{l}1 \\ 1 \\ . \\ 1 \\ 1\end{array}\right]$ Unit Vector $(i \times 1), i$ is the number of commodities

(4) $\beta=(\operatorname{diag} A)^{-1} U$

$\beta_{i j}=$ proportion of commodity $i$ sold to industry $j$

A cell in the $\beta$ matrix is the proportion in which the commodity in the row is consumed by the industry in the column. The sum of a row is equal to " 1 ," and a zero value in a cell implies no consumption of the commodity in the row by the industry in that column.

The national I-O coefficients must be regionalized to the state level. Location quotients, as shown in Table 7, are used to regionalize the national I-O coefficients (Liu and Vilain 2004). A location quotient of more than one implies a greater share in the economy by that industry at the state level compared to its share at the national level.

(5) $\mathrm{L}_{\text {state }}=\frac{(\% \text { of total state employment in industry } \mathrm{j})}{(\% \text { of total U.S. employment in industry j) }}$

$L_{\text {state }}=$ matrix $(1 \times j)$ ratio of state employment in industry $j$ to national employment in industry $j$ 
Table 6: User-defined 38 Categories and Corresponding NAICS

\begin{tabular}{|c|c|c|}
\hline Category & Description & Corresponding NAICS \\
\hline 1 & Farm Products & 1110,1120 \\
\hline 2 & Forest and fishing products & $1130,1140,1150$ \\
\hline 3 & Mining (mineral) products & $2110,2121,2122,2123,2130$ \\
\hline 4 & Construction & $2301,2302,2303$ \\
\hline 5 & Ordnance or accessories & $332 \mathrm{~A}$ \\
\hline 6 & Food or kindred products & 3110,3121 \\
\hline 7 & Tobacco products, excluding insecticides & 3122 \\
\hline 8 & Textile mill products & 3130,3140 \\
\hline 9 & Apparel or other finished textile products & 3150 \\
\hline 10 & Lumber or wood products, excluding furniture & 3210 \\
\hline 11 & Furniture or fixtures & 3370 \\
\hline 12 & Pulp, paper or allied products & 3221,3222 \\
\hline 13 & Printing matter & 3230 \\
\hline 14 & Chemical or allied products & $3251,3253,3259$ \\
\hline 15 & Petroleum or coal products & 3240 \\
\hline 16 & Rubber or miscellaneous plastics products & 3252,3260 \\
\hline 17 & Leather or leather products & 3160 \\
\hline 18 & Clay, concrete, glass or stone products & 3270 \\
\hline 19 & Primary metal products & $331 \mathrm{~A}, 331 \mathrm{~B}, 3315,3321,3322,3324$ \\
\hline 20 & Fabricated metal products & $332 \mathrm{~B}$ \\
\hline 21 & Machinery, excluding electrical & $3331,3332,3335$ \\
\hline 22 & Electrical machinery, equipment or supply & $3341,334 \mathrm{~A}, 3353,3359$ \\
\hline 23 & Transportation equipment & $3361,336 \mathrm{~A}, 336 \mathrm{~B}, 3364$ \\
\hline 24 & Instruments, photographic goods, optical good & 3333 \\
\hline 25 & Miscellaneous products or manufacturing & 3391,3399 \\
\hline 26 & Railroad transportation & 4820 \\
\hline 27 & Trucking and warehousing & 4840,4930 \\
\hline 28 & Water transportation & 4830 \\
\hline 29 & Other transportation & $4810,4850,48 \mathrm{~A} 0,4920$ \\
\hline 30 & Communications & $5111,5112,5120,5131,5132,5133,5141$ \\
\hline 31 & Electric, gas, and sanitary services & $5620,2211,2212,2213$ \\
\hline 32 & Wholesale trade & 4200 \\
\hline 33 & Retail trade & $4 \mathrm{~A} 00$ \\
\hline 34 & Finance, insurance, and real estate & $52 \mathrm{~A} 0,5230,5240,5250,5310,5321,5324$ \\
\hline 35 & Services & $5411,5412,5414,5415$ \\
\hline 36 & Government and government enterprises & S001, S002, S005 \\
\hline 37 & Others & S003, S004, S006, S007 \\
\hline 38 & Value added / final demand & \\
\hline
\end{tabular}


Table 7: State and National Location Quotient for Different NAICS Class

\begin{tabular}{crrr}
\hline NAICS & ND Employment & US Employment & $\mathbf{L}_{\mathbf{j}}$ \\
\hline 11 & 242 & 182,121 & 0.62 \\
21 & 2,324 & 470,280 & 2.34 \\
22 & 2,201 & 634,734 & 1.64 \\
23 & 13,760 & $6,647,641$ & 0.98 \\
31 & 20,112 & $13,821,976$ & 0.68 \\
32 & 5,684 & $3,980,178$ & 0.67 \\
33 & 15,256 & $7,485,582$ & 0.96 \\
42 & 15,887 & $5,907,051$ & 1.27 \\
44 & 41,813 & $15,351,431$ & 1.29 \\
48 & 8,342 & $4,098,870$ & 0.96 \\
51 & 6,977 & $3,472,427$ & 0.95 \\
52 & 13,299 & $6,481,304$ & 0.97 \\
53 & 3,285 & $2,086,085$ & 0.74 \\
54 & 10,790 & $7,569,981$ & 0.67 \\
55 & 2,774 & $2,824,787$ & 0.46 \\
56 & 10,118 & $8,708,052$ & 0.55 \\
61 & 2,979 & $2,893,346$ & 0.48 \\
62 & 49,571 & $15,814,812$ & 1.48 \\
71 & 2,563 & $1,889,044$ & 0.64 \\
72 & 25,727 & $10,749,811$ & 1.13 \\
81 & 13,187 & $5,416,193$ & 1.15 \\
\hline
\end{tabular}

(U.S. Census Bureau 2004a)

(6) $\beta_{\text {state }}=\beta \cdot\left(\right.$ diag $\left.L_{\text {state }}\right)$

$\beta_{\text {state }}=$ the supply side commodity-by-industry coefficient for the state

$\beta_{\text {state }}$ is more than $\beta$ for those commodities which have $L_{\text {state }}$ values more than one, and $\beta_{\text {state }}$ is less than $\beta$ for those commodities that have location quotients less than one. This is justified, as the industries that are predominant in the state as compared to its predominance in the nation will have higher proportion of consumption of commodities than at the national level. This is true under certain assumptions like homogeneity of goods, spatial uniformity of demand and none of the good is exported. The rationalization process changes the row sum of $\beta_{\text {state }}$, so an adjustment is necessary to make the row sum equal to one.

(7) $\gamma=\beta_{\text {state }} .1$

(8) $C=\operatorname{diag}\{\gamma\}^{-1} \beta_{\text {state }}$

$C$ = adjusted commodity by industry supply side I-O model for the state 
Statewide Freight Movement

(9) $D=C . C_{e}$

$C_{e}=$ employment matrix

$D=$ portion of commodity moving to the counties

(10) $D_{i k}=\sum_{j} C_{i j} C_{j k}$ (Co-ordinate form)

$D_{i k}=$ portion of commodity $i$ moving to county $k$

$C_{i j}=$ adjusted commodity $i$ by industry $j$ supply side I-O coefficient for the state

$C_{j k}=$ employment/population in industry/end-user $j$ in county $k$

(11) $\hat{D}=\operatorname{diag}\{\mathrm{D} \cdot 1\}^{-1} \mathrm{D}$

$\hat{\mathrm{D}}=$ adjusted $\mathrm{D}$ matrix making the row sum equal to one.

Each element of the $\hat{D}$ matrix represents the portion of commodity $i$ shipped to county $j$. This is the final matrix, which helps to disaggregate the commodities moving into the state to the county level based on the employment and population patterns of the state.

(12) $B_{i j k}=F_{l i} \cdot \hat{D}_{i k}$

$F_{l i}$ is the amount of commodity $i$ moving into the state from origin $l$

$i=$ commodity type, $k=$ county and $l=$ origin

$B_{i j k}$ is the OD matrix for different commodities ranging from 1 to $i$. The origin $l$ is outside state FAF region, and the destination $k$ is a county in the state.

\section{Internal-Internal Flow}

The internal-internal flow data for North Dakota are available from the FAF ${ }^{2}$ databases. These sets of data have their origins and destinations in North Dakota. The trip production data for this internalinternal dataset are disaggregated to the TAZ level, using the NAICS employment distribution. The freight attraction data are also disaggregated to the TAZ level, using the I-O table and the county employment pattern, as explained in detail in the previous section. Unlike the internal-external and the external-internal data, the internal-internal data have both their origin and destination disaggregated; hence, an additional step of trip distribution is required, to develop an OD matrix.

The internal-internal flows are distributed using a gravity model. Data for trip length distribution of manufactured goods in the state is available from a survey done at UGPTI (Vachal and Tolliver 2001). This trip length distribution data is used to calibrate the gravity model.

(13) $X_{i j}^{c}=\frac{P_{i}^{c} A_{j}^{c} F_{i j}}{\sum_{j}^{n} A_{j}^{c} F_{i j}} \forall c$

Where:

$\mathrm{X}_{\mathrm{ij}}^{\mathrm{c}}=$ flow of manufactured freight from TAZ $i$ to $\mathrm{TAZ}_{j}$

$\mathrm{P}_{\mathrm{i}}^{\mathrm{c}}=$ freight $c$ production in TAZ $i$

$\mathrm{A}_{\mathrm{j}}^{c}=$ attraction of freight $c$ at TAZ $j$ 
c = waste/scrap, gravel, gasoline, nonmetal mineral products, fuel oils, coal, other foodstuffs, unknown, animal feed, machinery, natural sands, mixed freight, wood products and live animals/fish

(14) $F_{i j}=\mathrm{f}\left(t_{i j}\right)=F_{i j}=a e^{-b t_{i j}}$; where $t_{i j}=$ travel impedance based on distance, $b=$ calibration factor, $a=$ coefficient

The gamma function for the impedance factor used is as follows:

(15) $F_{i j}=a e^{-b t_{i j}}$

$t_{i j}=$ travel impedance, $\mathrm{a}$ and $\mathrm{b}$ are coefficients

The log form of the function is used in a regression analysis to estimate the coefficients.

(16) $\ln \left(F_{i j}\right)=\ln (a)-b t_{i j}$

Coefficients $a$ and $b$ with values 12 and .025 give the best fit. The observed and model trip distributions are compared; the mean trip length for observed flow is 89 miles and estimated flow is 84 miles, which a is good fit. The major truck routes obtained from the internal-internal model are shown in Figure 4.

Figure 4: Major Truck Routes for the Internal-Internal Commodity Flow

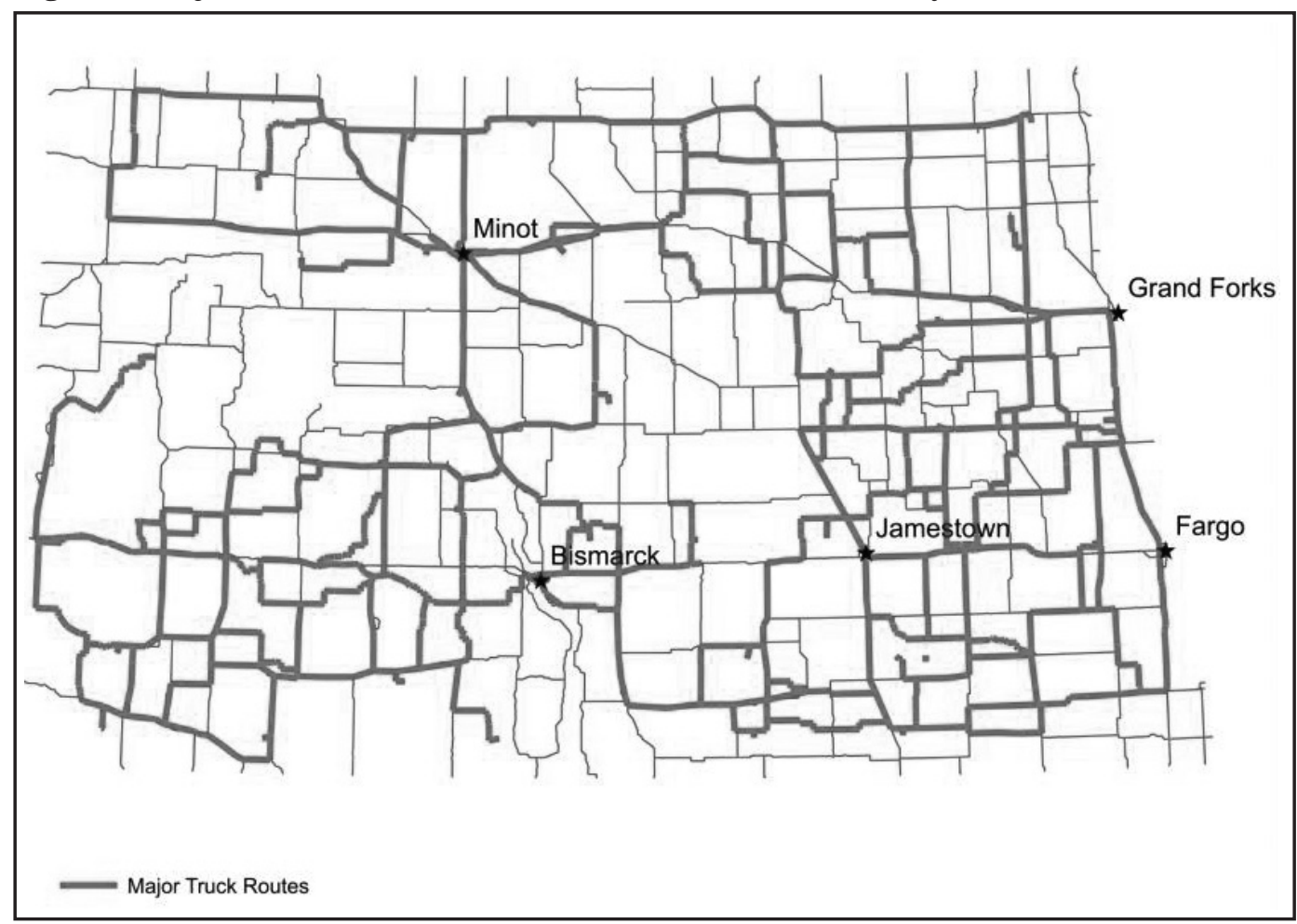




\section{Analyzing Cross-Border Traffic}

The FAF"s Microsoft Access database "FAFOD_2002.MDB" has a table named "FAFOD_ BRD_2002" that has data on cross border freight movement to neighboring countries, namely Canada and Mexico. An SQL query is done to extract freight movement between Canada and North Dakota. From the list of commodities moving to and from Canada, eight commodities and two ports of exit, as shown in Table 8, are selected. The two ports of exit are North Dakota and Detroit, Michigan. To model this flow, highways leaving the state at the northern state boundary are connected to provinces in Canada with dummy links, and for the Detroit port of exit it is assumed that the truck will travel via eastern exits of the state and then move to Canada through Detroit. This cross-border freight OD data is disaggregated to the TAZ level using county employment data, as has been done for domestic freight moving out of the state. The commodities moving in are disaggregated to the TAZs using the I-O table and the employment distribution pattern.

Table 8: Major Commodities Moving to Canada and the Port of Exit

\begin{tabular}{lrr}
\hline Commodity & \multicolumn{1}{c}{ Port } & Kilo-ton \\
\hline Animal feed & ND & 48.23 \\
Animal feed & MI Detroit & 10.2 \\
Cereal grains & MI Detroit & 14.31 \\
Cereal grains & ND & 67.69 \\
Coal & ND & 44.65 \\
Coal & MI Detroit & 9.44 \\
Fertilizers & MI Detroit & 3.63 \\
Fertilizers & ND & 17.16 \\
Machinery & ND & 11.31 \\
Machinery & MI Detroit & 2.39 \\
Motorized vehicles & MI Detroit & 1.57 \\
Motorized vehicles & ND & 7.42 \\
Other ag prods. & MI Detroit & 21.51 \\
Other ag prods. & ND & 101.77 \\
Other foodstuffs & MI Detroit & 1.86 \\
Other foodstuffs & ND & 8.78 \\
\hline
\end{tabular}

(U.S. Department of Transportation 2007a)

\section{Model Validation}

The statewide freight model is validated using truck count data from different sources. The truck count data for the state of North Dakota are available from cordon surveys, Highway Performance Monitoring System (HPMS), vehicle miles traveled (VMT) estimates and Roadway Information Management System (RIMS). In this project, the truck traffic assigned to the network from the agricultural goods flow model is merged with the manufactured goods flow model. There is another set of truck count data available from the North Dakota DOT's automatic traffic recording (ATR) stations. There are 38 permanent ATR stations in the state. These stations have directional truck count data for every single day of the year. For this project, the ATR station's annual truck traffic is used for validation and calibration of the estimated truck traffic. 
Statistical methods used to compare link traffic counts are absolute difference in volumes, percentage differences in volumes, average errors, average percent errors, standard deviations, R-square values, root mean square errors and correlation coefficients. Table 9 gives the observed and estimated link truck traffic. $O_{l}$ is the observed traffic and $E_{l}$ is the estimated traffic. The percent RMSE is calculated using equation 17, and results are shown in Table 10.

(17) $\%$ RMSE $=\frac{\left(\sum_{j}\left(\text { Model }_{j}-\text { Count }_{j}\right)^{2} /(\text { Number of Counts }-1)\right)^{.5} \times 100}{\left(\sum_{j} \text { Count }_{j} / \text { Number of Counts }\right)}$

Table 9: Absolute Percentage Error of Estimated Truck Traffic

\begin{tabular}{|c|c|c|c|c|}
\hline $\begin{array}{l}\text { Name of } \\
\text { highway }\end{array}$ & $O_{l}$ & $E_{l}$ & $O_{l}-E_{l}$ & $\left|\frac{O_{l}-E_{l}}{O_{l}}\right|(\%)$ \\
\hline S200 & 32,756 & 32,877 & -121 & $0.4 \%$ \\
\hline S200 & 40,243 & 40,424 & -181 & $0.5 \%$ \\
\hline $\mathrm{S} 200$ & 14,529 & 14,211 & 318 & $2.2 \%$ \\
\hline S200 & 14,306 & 14,372 & -66 & $0.5 \%$ \\
\hline U2 & 52,985 & 51,791 & 1,194 & $2.3 \%$ \\
\hline $\mathrm{U} 2$ & 52,373 & 52,061 & 312 & $0.6 \%$ \\
\hline U83 & 95,051 & 96,142 & $-1,091$ & $1.1 \%$ \\
\hline U83 & 84,270 & 86,343 & $-2,073$ & $2.5 \%$ \\
\hline $\mathrm{S} 13$ & 24,071 & 23,913 & 158 & $0.7 \%$ \\
\hline $\mathrm{S} 13$ & 28,225 & 28,023 & 202 & $0.7 \%$ \\
\hline I94 & 278,715 & 282,127 & $-3,412$ & $1.2 \%$ \\
\hline I94 & 263,952 & 265,950 & $-1,998$ & $0.8 \%$ \\
\hline I 29 & 437,825 & 404,157 & 33,668 & $7.7 \%$ \\
\hline I 29 & 439,472 & 432,766 & 6,706 & $1.5 \%$ \\
\hline U83 & 94,963 & 96,090 & $-1,127$ & $1.2 \%$ \\
\hline U52 & 100,815 & 101,751 & -936 & $0.9 \%$ \\
\hline I94 & 758,577 & 742,380 & 16,197 & $2.1 \%$ \\
\hline I94 & 691,500 & 675,439 & 16,061 & $2.3 \%$ \\
\hline I29 & 244,162 & 245,567 & $-1,405$ & $0.6 \%$ \\
\hline I29 & 259,734 & 264,967 & $-5,233$ & $2.0 \%$ \\
\hline $\mathrm{S} 1$ & 20,063 & 20,072 & -9 & $0.0 \%$ \\
\hline $\mathrm{S} 1$ & 20,221 & 20,292 & -71 & $0.3 \%$ \\
\hline
\end{tabular}


Table 10: Percent Root Mean Square

\begin{tabular}{lc}
\hline Truck counts & \% RMSE \\
\hline$<50,000$ & 1.47 \\
$50,000-100,000$ & 1.36 \\
$100,000-150,000$ & .47 \\
$150,000-200,000$ & 9.04 \\
$200,000-250,000$ & 8.99 \\
$250,000-300,000$ & 1.42 \\
$300,000-350,000$ & .86 \\
$>350,000$ & 3.30 \\
\hline
\end{tabular}

\section{CONCLUSION}

This research process, along with its findings, contributes to building a framework for integrating statewide agricultural freight flow models with that of manufactured goods flow. The micro-level disaggregation of the total flows into sub-modules helps to analyze the effect of external factors on freight travel demand in greater detail. In statewide freight modeling, availability of data is a big concern for most states. In this research, most of the freight data are generated from publicly available databases. One of the prime sources of the agricultural freight model is satellite imagery, which is freely available from the National Agricultural Statistics Service (NASS). This data can be used not only for statewide study, but also for more detailed study of smaller regions at county or sub-county levels.

FAF $^{2}$ data that fill the void of the CFS data are utilized for this statewide freight modeling purpose. This modeling framework, with the successful outcome, will help build confidence in using publicly available data in the absence of proprietary data. Implan (Minnesota Implan Group 2007) is used by many states for disaggregation of trips to the TAZ level. In this project, it demonstrated how, in the absence of this software, data from heterogeneous sources like Bureau of Transportation Statistic's I-O account data, county employment data and local survey results can be used to disaggregate trips to the TAZ level.

In freight demand modeling, the base origin/destination matrix does not always represent the actual freight movement, as there can be many intermediate legs in the OD flow. There can be a number of warehouses and distribution centers between the origin and final destinations. Most of the available data do include these shipment legs. In this project, a matrix estimation method is used to introduce these distribution legs by updating the estimated OD matrix with the available link count data. All the innovative methods introduced in this statewide freight model are a stride toward the development of robust statewide freight modeling methodologies.

\section{Endnotes}

1. Henceforth referred to as "manufactured goods/freight" for convenience.

2. FAF data is used in this project to generate OD data, and it is disaggregated and assigned using the models described in the paper. The FAF freight incorrectly assigned to highway segments in some states is not used in this project. 


\section{References}

Bureau of Economic Analysis 2005. Benchmark Input-Output Accounts, The Use of Commodities by Industries before Redefinitions. http://www.bea.gov/bea/dn2/home/benchmark.htm, Accessed March 9, 2006.

Bureau of Transportation Statistics. Directory of Transportation Data Sources. U.S. Department of Transportation, Washington, D.C., 1995.

Bureau of Transportation Statistics. Freight Data and Statistics. U.S. Department of Transportation, Washington, D.C., 2007.

De Jong, G. and M.E. Ben-Akiva. “A Micro-simulation Model of Shipment Size and Transportation Chain Choice." Transportation Research Part B 41, (2007): 950-965.

Donnelly, R. National Freight Data Program. Transportation Research Board Special Report 276, Transportation National Research Council, Washington, D.C., 2003.

Global Insight. Transearch. http://www.globalinsight.com/ProductsServices/ProductDetail 2322. htm, Accessed March 9, 2006.

Lawson, A.M., K.S. Bersani, M.F. Nader, and J. Guo. Benchmark Input-Output Accounts of the United States. Bureau of Economic Analysis, Online articles and other documents, 1997.

Liu, L.N. and P. Vilain. "Estimating Commodity Inflows to a Substate Region Using Input-Output Data." Journal of Transportation and Statistics 7(1), (2004): 23-38.

Memmott, W.F. Application of Statewide Freight Demand Forecasting Techniques. NCHRP Report 260: Transportation Research Board, National Research Council, Washington, D.C., 1983.

Minnesota Implan Group. Implan. http://implan.com, Accessed January 7, 2007.

Mitra, S., D. Tolliver, A. Varma, and A. Dybing. "Analyzing the Effects of Spring Highway Load Restrictions on North Dakota's Agricultural Freight Flows." Transportation Research Record 2008 (2007): 92-99.

Roger Creighton Associates, Inc. and R.L. Banks \& Associates, Inc. NCHRP Research Report 177: Freight Data Requirements for Statewide Transportation Systems Planning. Transportation Research Board, National Research Council, Washington, D.C., 1977.

Surface Transportation Board. Economic Data: Waybill. http://www.census.gov/epcd/ cbp/ download/dwncbp04.html, Accessed January 7, 2007.

U.S. Army Corps of Engineers. Waterborne Commerce Statistics Center. http://www.iwr.usace. army.mil/ndc/wcsc/wcsc.htm, Accessed January 8, 2007.

U.S. Census Bureau. County Business Patterns: 2004. http://www.census.gov/epcd/cbp /download dwncbp04.htm, Accessed January 7, 2007a.

U.S. Census Bureau. 2002, Commodity Flow Survey. http://www.census.gov/svsd/www/ cfsdat/2002cfs.html, Accessed January 8, 2007b.

U.S. Department of Transportation. Federal Highway Administration. Freight Analysis Framework. http://ops.fhwa.dot.gov/freight/freightanalysis/faf.index.htm, Accessed January 4, 2007a. 
U.S. Department of Transportation. Federal Highway Administration. Freight Model Improvement Program. http://www.freight.dot.gov/fmip, Accessed January 7, 2007b.

U.S. Department of Transportation. Federal Highway Administration. Geofreight Intermodal Freight Display Tool. http://www.fhwa.dot.gov/freightplanning/geofreight.htm, Accessed January $8,2007 \mathrm{c}$.

U.S. Department of Transportation. Federal Highway Administration. Maritime Statistics. http:// www.marad.dot.gov/library_landing_page/data_and_tatistics/Data_and_Statistics.htm, Accessed January 9, 2007d.

Vachal, K. and D. Tolliver. Regional Elevator Survey: Grain Transportation and Industry Trends for Great Plains Elevators. Upper Great Plains Transportation Institute, Fargo, ND, Report No. DP-143. 2001.

Subhro Mitra is an associate research fellow at the Upper Great Plains Transportation Institute at North Dakota State University. He is also a faculty member in NDSU's Transportation Logistics Ph.D. program and an adjunct professor in the civil engineering department. He holds a Ph.D. in transportation and logistics from NDSU and has 14 years of diverse work experience in both operational and technical aspects of transportation and highway engineering. He is a registered professional engineer of the State of North Dakota.

Denver Tolliver is associate director of the Upper Great Plains Transportation Institute and director of the Transportation \& Logistics program at North Dakota State University. He is also director of the Mountain-Plains Consortium (MPC) — which is the regional university transportation center for federal region 8. Tolliver is a long-time member of TRF and a former president of the Agricultural Transportation chapter. His primary research interests are highway, railroad, and inland waterway planning. Tolliver holds doctoral and master degrees from Virginia Tech and a baccalaureate degree from Morehead State. Before joining the faculty of North Dakota State University, he was a transportation planner for the North Dakota Department of Transportation. 